\title{
Regulation of epidermal growth factor expression in mammary epithelial cells by a Yin-Yang-1-like element
}

\section{Y Fang and L G Sheffield}

Endocrinology-Reproductive Physiology Program, 266 Animal Sciences Building, 1675 Observatory Drive, University of Wisconsin, Madison, Wisconsin 53706, USA

(Requests for offprints should be addressed to L G Sheffield)

\begin{abstract}
The hormone combination of insulin, dexamethasone and prolactin induced accumulation of preproepidermal growth factor (EGF) mRNA in HC11 mouse mammary epithelial cells 16-24 h after the hormones were added to the cultures. Individual hormones or combinations of two of the hormones had no effect on EGF mRNA concentrations. The same hormone combination was capable of inducing expression of a reporter gene construct containing -888 to $+25 \mathrm{bp}$ of the EGF gene fused with luciferase. Deletions of the promoter between -888 and $-271 \mathrm{bp}$ had no detectable effect on basal or hormone-induced reporter gene expression. However, further deletion from -270 to $-74 \mathrm{bp}$ increased baseline to approximately
\end{abstract}

equal hormone-induced reporter gene expression. This deletion also abolished the hormone-induced increase in reporter gene expression. Sequence analysis suggested that this region contained a binding site for Yin-Yang-1 (YY1), which was confirmed by gelshift analysis. Mutation of the YY1 binding site increased baseline reporter gene expression to the same level as induced by insulin, dexamethasone and prolactin in the wild-type promoter. These results indicate that expression of the EGF gene in mammary epithelium is repressed by the YY1 site, and that removal of repression may play a part in regulating EGF gene expression in lactating mammary tissue.

Fournal of Molecular Endocrinology (1998) 20, 337-344

\section{INTRODUCTION}

Epidermal growth factor (EGF) is a 53 amino acid peptide present in a variety of tissues and fluids, including milk (Carpenter 1980, Beardmore \& Richards 1983, Mroczkowski \& Reich 1993). It is synthesized as a 1217 amino acid glycoprotein (preproEGF), which contains the authentic EGF peptide and seven other EGF-like repeats (Gray et al. 1983, Scott et al. 1983). PreproEGF is processed via kallikrein-like enzymes to mature EGF and possibly a variety of other molecules also (Jahnke et al. 1994). In the lactating mammary gland, EGF appears to be apically localized (Brown et al. 1989).

EGF mRNA has been detected in mammary tissue (Brown et al. 1989) and appears to be more abundant in lactating tissue. EGF mRNA appears to localize to epithelial cells in the mammary gland (Snedeker et al. 1991). The lactogenic hormones insulin, hydrocortisone and prolactin are capable of inducing EGF mRNA accumulation in mouse mammary organ cultures (Fenton \& Sheffield 1991).
Furthermore, EGF mRNA has been reported in mammary epithelial cell lines and found to be increased by prolactin (Fenton \& Sheffield 1994). In vivo, insulin has been shown to regulate the EGF content of rat milk (Thulesen et al. 1993). These relationships appear different than those in the salivary gland and kidney (both of which are major sites of EGF expression; Fisher \& Lakshmanan 1990), in which androgens and thyroid hormones are major regulators of EGF expression (Gubits et al. 1986, Kasayama et al. 1989, Pascall et al. 1989).

Pascall \& Brown (1988) cloned the $5^{\prime}$ flanking region of EGF and have subsequently shown that a $5.5 \mathrm{~kb}$ fragment of the $5^{\prime}$ flank resulted in tissue-specific and hormone-responsive expression of the SV40 $\mathrm{T}$ antigen in transgenic mice (Pascall et al. 1994). Price et al. (1995) found that a $1010 \mathrm{bp}$ fragment of the rat EGF promoter responded to renal ischemia in a manner similar to that of the endogenous EGF gene. Fenton et al. (1996) reported the ability of an approximately $2 \mathrm{~kb}$ clone of the EGF 5' flank to drive EGF expression in cell 
lines. None of these studies have yet identified the specific DNA sequences responsible for hormonal regulation of EGF transcription. Also, little is known about the regulation of EGF production by mammary tissue at a molecular level. Therefore, the objective of the present study was to define further the molecular control of EGF expression in mammary epithelium.

\section{MATERIALS AND METHODS}

\section{Cell culture and treatment}

HC11 mouse mammary epithelial cells (Ball et al. 1988) were obtained via Dr J Rosen with permission of the line's originator, Dr B Groner (Institute for Experimental Cancer, Freiburg, Germany). Cells were routinely grown in RPMI 1640 supplemented with $10 \%$ fetal bovine serum, $5 \mu \mathrm{g} / \mathrm{ml}$ insulin and $10 \mathrm{ng} / \mathrm{ml} \mathrm{EGF}$ (growth medium). Culture was at $37^{\circ} \mathrm{C}$ in a humidified atmosphere of $95 \%$ air $-5 \%$ $\mathrm{CO}_{2}$. For lactogenic hormone treatment, cells were allowed to grow to confluence and remain confluent for 1 day, after which the medium was changed to RPMI 1640 supplemented with $10 \%$ gelding serum, $1 \mu \mathrm{g} / \mathrm{ml}$ insulin, $0 \cdot 1 \mu \mathrm{M}$ dexamethasone and $100 \mathrm{ng} /$ $\mathrm{ml}$ ovine prolactin. Standard lactogenic treatment was for $24 \mathrm{~h}$. However, for specific studies, other times and other hormone combinations were also used.

\section{mRNA determination}

To prepare an EGF RNA probe, a 361 bp DNA fragment corresponding to $3489-3850 \mathrm{bp}$ of preproEGF cDNA was subcloned from pmegf1 (ATCC, Rockville, MD, USA) into pGEM-7Zf (Promega, Madison, WI, USA). The plasmid was then grown in $E$. coli $\mathrm{DH} 5 \alpha$ and purified using Clear-Cut mini-prep kit (Stratagene, La Jolla, CA, USA). The resulting plasmid was linearized with $\mathrm{XbaI}$ and digitonin-labeled RNA synthesized from the SP6 promoter to give an antisense RNA. The reaction mixture was $20 \mu \mathrm{l}$ and contained $1 \mu \mathrm{g}$ linerized plasmid, $1 \mathrm{mM}$ each ATP, CTP and GTP, $0.65 \mathrm{mM}$ UTP, $0.35 \mathrm{mM}$ digitonin-UTP, $40 \mathrm{mM}$ Tris, $\mathrm{pH} 8 \cdot 0,6 \mathrm{mM} \mathrm{MgCl}_{2}, 10 \mathrm{mM}$ dithiothreitol (DTT), $2 \mathrm{mM}$ spermidine, $10 \mathrm{mM} \mathrm{NaCl}, 0.05 \mathrm{U}$ RNase inhibitor and $40 \mathrm{U}$ SP6 RNA polymerase. Reactions were continued at $37^{\circ} \mathrm{C}$ for $2 \mathrm{~h}$, followed by addition of DNase I for $15 \mathrm{~min}$ and final addition of $2 \mu \mathrm{l}$ of a $200 \mathrm{mM}$ EDTA solution.

Total cytoplasmic RNA was isolated from HC11 cells grown in $60 \mathrm{~mm}$ dishes (approximately $5 \times 10^{6}$ cells per dish) as previously described (Chomczynski \& Sacchi 1987). RNA $(10 \mu \mathrm{g})$ was separated on a $1 \%$ agarose gel containing $3 \%$ formaldehyde and transferred to nylon membranes (Boehringer Mannheim Co., Indianapolis, IN, USA) by capillary transfer in $10 \times \mathrm{SSC}(1.5 \mathrm{M} \mathrm{NaCl}, 150 \mathrm{mM}$ sodium citrate). Membranes were u.v. crosslinked and probed using the digitonin-labeled RNA probe and the Genius detection system (Boehringer Mannhein). Briefly, blots were incubated for $2 \mathrm{~h}$ at $68{ }^{\circ} \mathrm{C}$ in hybridization buffer containing $50 \%$ formamide, $5 \times \mathrm{SSC}, \quad 0 \cdot 1 \% \quad \mathrm{~N}$-lauroylsarcosine, $0.02 \%$ SDS and 2\% blocking reagent (Boehringer Mannheim). Digitonin-labeled EGF probe (40 $\mathrm{ng} /$ $\mathrm{ml}$ ) was added and hybridization continued for $18 \mathrm{~h}$. The membrane was washed twice for $5 \mathrm{~min}$ each with $2 \times \mathrm{SSC}$ containing $0.1 \%$ SDS at room temperature and twice for $15 \mathrm{~min}$ each with $0.5 \%$ SSC containing $0 \cdot 1 \% \mathrm{SDS}$ at $72{ }^{\circ} \mathrm{C}$. The membrane was then incubated with alkaline phosphatase conjugated anti-digitonin, washed twice and detection of reactive bands performed by chemiluminescence (CDP-Star, Boehringer Mannheim). Computer assisted densitometry was used to determine relative amounts of EGF $\mathrm{mRNA}$, which was adjusted for equal amounts of $18 \mathrm{~S}$ rRNA, determined by ethidium bromide fluorescence (Collage, Fotodyne, New Berlin, WI, USA).

\section{Reporter gene constructs}

Various lengths of the EGF 5' flank were subcloned from p5'EGF (Pascall \& Brown 1988) by PCR using primers with HindIII and XhoI tails to facilitate cloning. These fragments were subcloned into the HindIII-XhoI site of pGL2basic (Promega) and amplified in $E$. coli DH5 $\alpha$. In addition, pGL2 basic with no promoter was used as a negative control and pGL2Control (Promega), which contains luciferase driven by an SV40 promoter/enhancer sequence, was used as a positive control.

To prepare mutations in the Yin-Yang-1 (YY1) site in the EGF gene, the wild-type construct consisting of -238 to $+25 \mathrm{bp}$ was prepared as described above. A $2 \mathrm{bp}$ mutation (the wild AACCATT was mutated to AACTAGT) was inserted by polymerase chain reaction using a mutagenic 5' primer (Kadowaki et al. 1989).

\section{Transfection studies}

HC11 cells were grown as described above. Approximately $10^{7}$ cells were suspended in $0.5 \mathrm{ml}$ Hanks's balanced salt solution (HBSS), together with $10 \mu \mathrm{g}$ purified plasmid DNA in an electroporation cuvet with $2 \mathrm{~mm}$ electrode space. Cells were transfected by electroporation with a $2 \mathrm{kV} / \mathrm{cm}$ field strength, incubated on ice in HBSS for 
5 min and plated in culture media at a density of $5 \times 10^{5} / \mathrm{cm}^{2}$. Cells were attached and grown for $24 \mathrm{~h}$ in growth medium, then subjected to lactogenic hormone treatments as described above. Luciferase expression was assessed using a commercial luciferase assay system (Promega).

\section{Gelshift analysis}

Nuclear extracts of control or lactogenic hormonetreated HC11 cells were prepared as previously described (Ye et al. 1994) and protein determined by bicinchoninic acid assay (Pierce, Rockford, IL, USA). Double-stranded DNA sequences corresponding to -250 to $-215 \mathrm{bp}$ of the EGF 5' flank sequence were synthesized (Gibco/BRL, Gaithersberg, MD, USA), labeled with polynucleotide kinase (Promega) and incubated at room temperature with nuclear extracts in $20 \mu \mathrm{l}$ of an assay mixture consisting of $6 \mu \mathrm{g}$ nuclear extract protein, $1 \mu \mathrm{g}$ poly $\mathrm{d}(\mathrm{I}-\mathrm{C}), 3 \mu \mathrm{g}$ BSA, 4\% Ficoll, $20 \mathrm{mM}$ Tris, pH 7.4, $60 \mathrm{mM} \mathrm{KCl,} 2 \mathrm{mM}$ EDTA, $0.5 \mathrm{mM}$ DTT and $10^{6}$ d.p.m. of ${ }^{32}$ P-labeled oligonucleotide probe. After $25 \mathrm{~min}$, samples were separated by $6 \%$ PAGE electrophoresis and X-ray film (Fuji Photofilm Co., Japan) was exposed to the gels. In addition, oligonucleotides containing a $2 \mathrm{bp}$ mutation (AACCATT sequence mutated to AACTAGT) were used as negative controls. Also, samples were incubated with anti-YY1 (Santa Cruz Biotechnology Inc., Santa Cruz, CA, USA) before gelshift, to verify the identity of YY1.

\section{Statistical analysis}

Data were analyzed by analysis of variance as a randomized complete block design (replicate= block). Means were compared with controls by Dunnett's test with the significance level set at $P<0 \cdot 05$ (Steel \& Torrie 1980).

\section{RESULTS}

Initial studies, in which cells were treated with combinations of insulin, dexamethasone and prolactin, revealed that only the combination of all three hormones was capable of increasing preproEGF mRNA accumulation in $\mathrm{HC} 11$ cells. In the absence of all three hormones, very little preproEGF mRNA was detected (Fig. 1). Time-course studies indicated that there was no detectable change in preproEGF mRNA $12 \mathrm{~h}$ after the hormones were added. PreproEGF mRNA content of cells was near maximum $16 \mathrm{~h}$ after the hormone combination was added and remained increased after $24 \mathrm{~h}$ (Fig. 1).
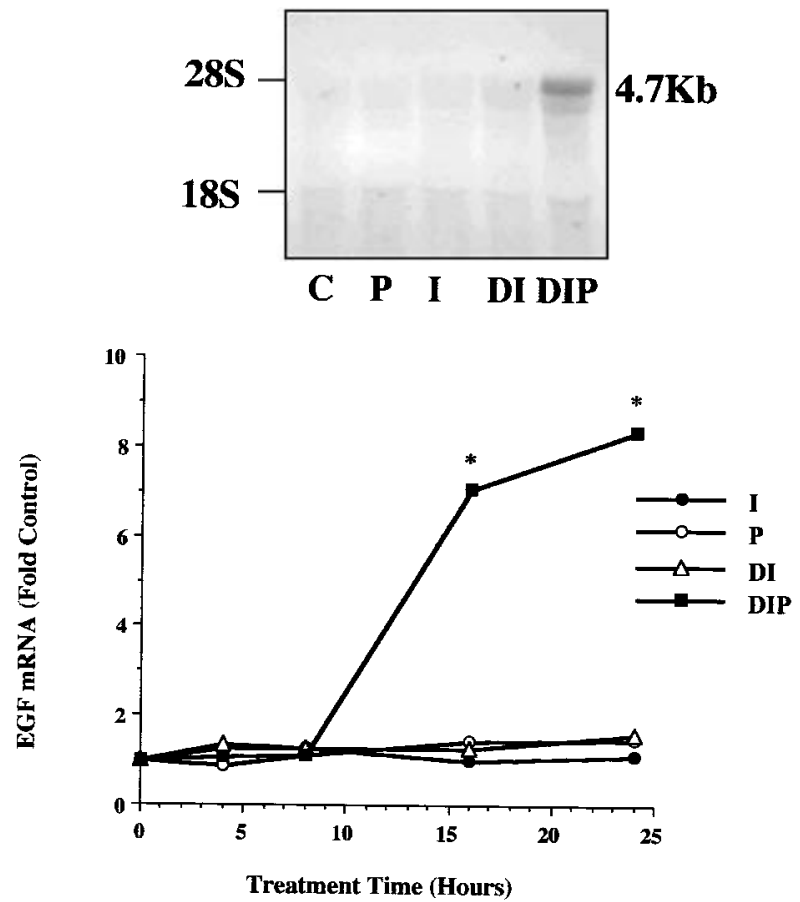

FIGURE 1. Accumulation of EGF mRNA in HC11 cells after treatment with combinations of insulin $(\mathrm{I}, 1 \mu \mathrm{g} / \mathrm{ml})$, dexamethasone $(\mathrm{D}, 0 \cdot 1 \mu \mathrm{M})$ and prolactin $(\mathrm{P}, 100 \mathrm{ng} / \mathrm{ml})$ for various times. Top: representative northern blot and ethidium bromide-stained RNA gel showing EGF mRNA $24 \mathrm{~h}$ after the addition of treatments. Graph: mean densitometry estimates of EGF mRNA expression, relative to $0 \mathrm{~h}$ control. $n=3$. s.E.M. averaged $12 \%$ and is not shown, for simplicity. * Significantly greater than $0 \mathrm{~h}$ control, $P<0 \cdot 05$.

Initial dose-response studies (not shown) indicated that $100 \mathrm{ng} / \mathrm{ml}$ prolactin gave the greatest response. A lower concentration $(10 \mathrm{ng} / \mathrm{ml}$ in the presence of dexamethasone and insulin) resulted in little stimulation of preproEGF mRNA accumulation, and $1 \mu \mathrm{g} / \mathrm{ml}$ resulted in no greater a response than was obtained with $100 \mathrm{ng} / \mathrm{ml}$. An insulin concentration of $100 \mathrm{ng} / \mathrm{ml}$ was ineffective in supporting EGF production in the presence of $100 \mathrm{ng} / \mathrm{ml}$ prolactin and $0 \cdot 1 \mu \mathrm{M}$ dexamethasone, but 1 or $10 \mu \mathrm{g} / \mathrm{ml}$ gave maximum induction of preproEGF mRNA. Dexamethasone concentrations of either $0 \cdot 1$ or $1 \mu \mathrm{M}$ resulted in lower EGF mRNA accumulation in the presence of $100 \mathrm{ng} / \mathrm{ml}$ prolactin and $1 \mu \mathrm{g} / \mathrm{ml}$ insulin than was achieved with $0 \cdot 1 \mu \mathrm{M}$ dexamethasone.

A DNA sequence consisting of -888 to $+25 \mathrm{bp}$ of the EGF 5' flanking region was also hormonally responsive upon transient transfection into $\mathrm{HC} 11$ cells (Fig. 2). Plasmids lacking the promoter region did not express detectable luciferase (not shown). 


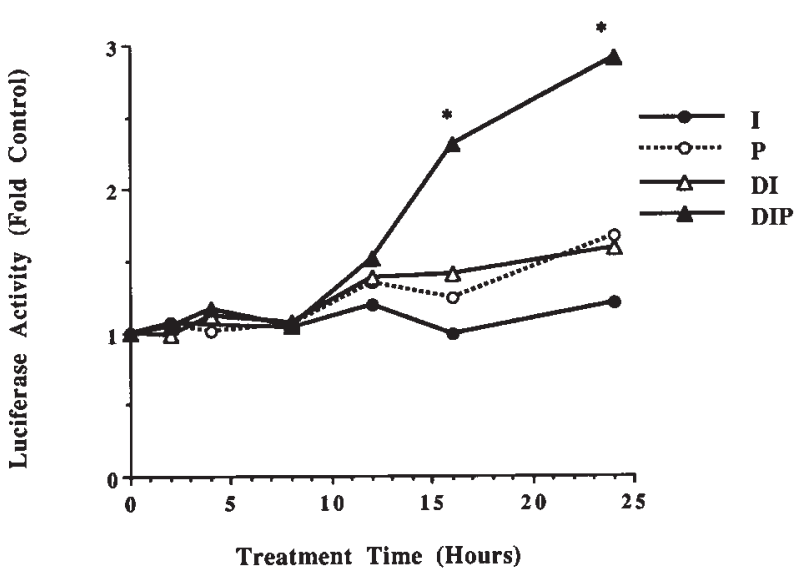

FIGURE 2. Luciferase activity in HC11 cells transiently transfected with luciferase driven by -888 to +25 bp of the EGF gene and treated with combinations of insulin $(\mathrm{I}, 1 \mu \mathrm{g} / \mathrm{ml})$, dexamethasone $(\mathrm{D}, 0 \cdot 1 \mu \mathrm{M})$ and prolactin $(\mathrm{P}, 100 \mathrm{ng} / \mathrm{ml})$ for various times. Mean luciferase activity, relative to $0 \mathrm{~h}$ control. $n=3$. s.E.M. averaged $9 \%$, and is not shown, for simplicity. * Significantly greater than $0 \mathrm{~h}$ control, $P<0 \cdot 05$.

Luciferase expression driven by an SV40 promoter and enhancer was readily detected (about three- to fivefold that of the baseline of the EGF promoter), but was not affected by hormone treatment (not shown). The hormone requirement for induction of luciferase expression was similar to that of the endogenous gene, in that all three hormones were required for maximum induction of luciferase expression. The time course of induction of expression of luciferase by insulin, dexamethasone and prolactin was similar to that observed for the endogenous EGF gene.

Deletion analysis (Fig. 3) indicated that deletions between -888 and $-271 \mathrm{bp}$ had no effect on either baseline or hormone-induced reporter gene expression. However, when the region between -270 and $-74 \mathrm{bp}$ was further deleted, a major change in reporter expression was observed. Baseline expression of luciferase driven by the $-73 /+25 \mathrm{bp}$ promoter construct was increased over that observed with the baseline of the $-270 /+25 \mathrm{bp}$ construct, and was equivalent to the hormoneinduced levels observed with longer constructs. The combination of insulin, dexamethasone and prolactin did not affect expression of luciferase driven by -73 to $+25 \mathrm{bp}$ of the EGF gene.

The sequence of the -270 to -74 region of the EGF gene indicated the presence of a likely binding site for YY1 (Fig. 4). Gelshift analysis (Fig. 5) indicated that this site was indeed capable of binding YY1. Nuclear extracts of HC11 cells were capable of inducing a strong gelshift, which was

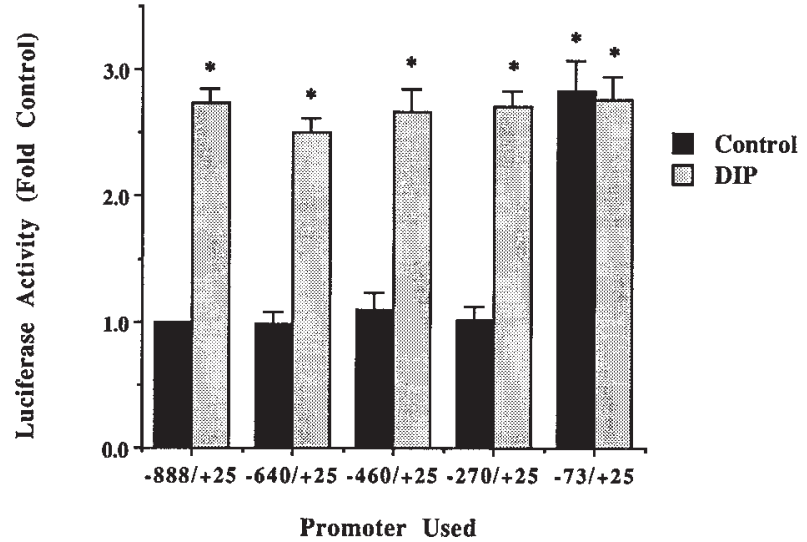

FIGURE 3. Luciferase activity in HC11 cells transiently transfected with luciferase driven by indicated fragments of the $5^{\prime}$ flank of the EGF gene and treated with no hormones (solid columns) or with insulin $(1 \mu \mathrm{g} / \mathrm{ml})$, dexamethasone $(0 \cdot 1 \mu \mathrm{M})$ and prolactin $(100 \mathrm{ng} / \mathrm{ml})$ (shaded columns) for $24 \mathrm{~h}$. Mean luciferase activity, relative to no hormone, $-888 /+25$ promoter \pm S.E.M. of densitometry estimates of EGF mRNA expression. $n=3$. * Significantly greater than the no hormone, $-888 /+25$ promoter, $P<0 \cdot 05$.

inhibited by anti-YY1 or excess unlabeled DNA, but not by an oligonucleotide containing a $2 \mathrm{bp}$ mutation. Anti-YY1 blocked the gelshift induced by nuclear proteins from $\mathrm{HC} 11$ cells. Interestingly, little difference in YY1-DNA interaction was observed between control and hormone-treated nuclear extracts. In addition to the YY1 complex (identified by antibody inhibition studies), these studies also demonstrated two additional mobility shifts. One, of less mobility than the YY1 complex, was inhibited by 50 -fold excess unlabeled oligonucleotide, but not by anti-YY1, and appeared to be independent of hormone treatment. The second complex, of greater mobility (lower on gel) than the YY1 complex, was inhibited by excess wildtype oligonucleotide, but not by excess mutated

Wild Sequence $\quad \begin{gathered}-250 \\ 5\end{gathered}$ TCA GCA GGT CCC TGG AAC CAT TAG CTG TGC CAC ACC $3^{\prime}$

Mutated Sequence 5' TCA GCA GGT CCC TGG AAC A TAG CTG TGC CAC ACC 3'

FIGURE 4. Sequence analysis showing the presence of a YY1-like element in the $5^{\prime}$ flank of the EGF gene.

Sequence as reported by Pascall \& Brown (1988) and Fenton et al. (1996). Wild sequence is the actual DNA sequence, with solid underline indicating the putative YY1 binding site and dashed underline indicating cryptic glucocorticoid receptor binding half-sites. Mutated sequence indicates the mutation induced in the putative YY1 binding site in subsequent gelshift and reporter gene analysis (mutated bases indicated by outline). 


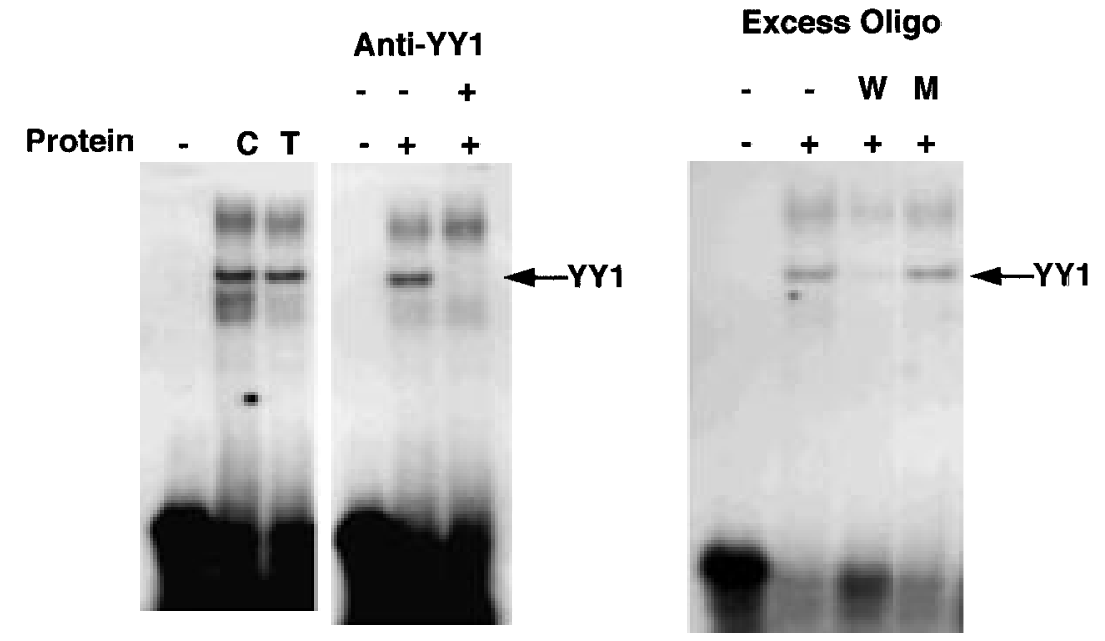

FIGURE 5. Gelshift analysis showing YY1 binding to the putative YY1 element in the EGF gene. Nuclear extracts from control (C) and hormone-treated (T) HC11 cells were prepared and gelshifts performed as described in Materials and Methods, using labeled wild-type oligonucleotides as a probe. In some studies, anti-YY1 was also added. In other studies, 50-fold excess unlabeled wild type oligonucleotide (W) or oligonucleotides mutated to remove YY1 binding (M) were also added. Representatives of three experiments.

oligonucleotide, suggesting that the complex may involve the YY1 sequence or an overlaping sequence. However, formation of this complex was not inhibited by anti-YY1. Interestingly, the formation of this complex appeared to be inhibited in hormone-treated cells.

In order to test more definitively whether or not the YY1 binding site has a role in regulating EGF expression, the YY1 site was mutated using the same $2 \mathrm{bp}$ mutation that had been shown in gelshift analysis not to interact with YY1. The wild-type construct consisting of -238 to $+25 \mathrm{bp}$ of the EGF gene exhibited hormone-responsive expression similar to the -888 to +25 bp construct in previous studies. Mutation of the YY1 site resulted in a reporter gene expression pattern similar to the -73 to +25 bp construct: the baseline was increased to approximately equal that of the hormone-induced wild-type construct, and hormone responsiveness was abolished (Fig. 6).

\section{DISCUSSION}

Results of these studies indicate that HC11 cells express EGF, and that EGF expression in this cell line is responsive to the lactogenic complex of insulin, dexamethasone and prolactin. These results are similar to those from previous reports showing that a similar hormone mixture induced EGF mRNA accumulation in mammary organ cultures (Fenton \& Sheffield 1991). Furthermore, these results suggest that this expression is at least partly under the control of $5^{\prime}$ regulatory sequences in the EGF gene. Previously, Fenton et al. (1996) observed that $5^{\prime}$ flanking sequences of EGF could drive reporter gene expression in various cell lines. They also reported that the effect of deletion of the EGF 5' flank was highly variable among cell lines, suggesting differential mechanisms of regulation in diverse cells. This observation is consistent with other studies showing substantial variation in the hormonal regulation of EGF expression among tissues (Gubits et al. 1986, Pascall et al. 1989).

The pattern of EGF expression in HC11 cells was reminiscent of milk protein expression, at least in terms of the hormonal requirements. The combination of insulin, a glucocorticoid and prolactin are well established as minimum requirements for milk protein synthesis (Topper \& Freeman 1980). However, the time course of EGF expression (both the endogenous gene and the reporter construct) was somewhat longer than that usually reported for milk proteins such as $\beta$-casein. Whether this represents a fundamental difference in the signaling pathways used in the induction of $\beta$-casein and EGF genes is unclear. However, the fact that the $5^{\prime}$ flank of EGF does not appear to contain any 


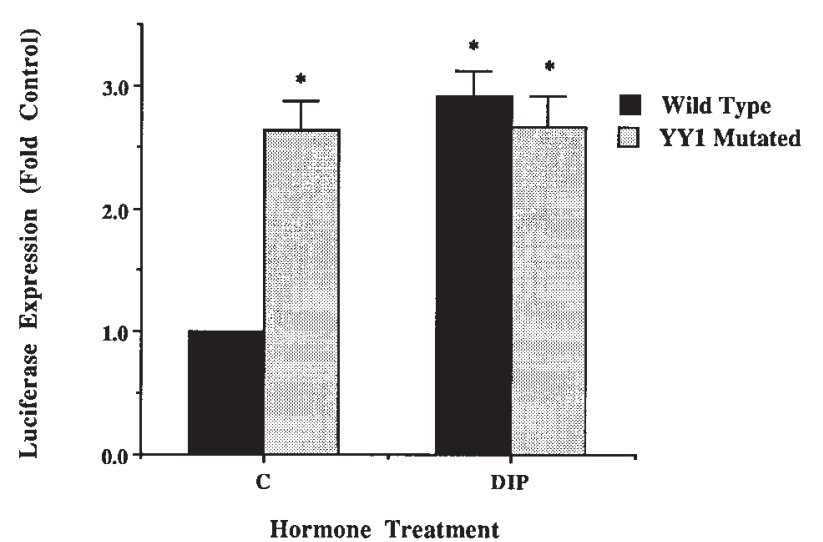

FIGURE 6. Effect of mutation of the putative YY1 site in the EGF gene on luciferase activity in HC11 cells transfected with wild-type (solid columns) or mutated (shaded columns) constructs and treated with no hormones (C) or insulin, dexamethasone and prolactin (DIP) as described in Materials and Methods. Mean \pm s.E.M. of three experiments. *Significantly greater than wild-type transfection, no hormone treatment, $P<0 \cdot 05$.

element resembling a STAT5 binding sequence suggests that the genes may be regulated by different mechanisms. STAT5 phosphorylation and DNA binding (in response to JAK2 activation by prolactin receptor) is believed to be a critical signal by which prolactin activates $\beta$-casein transcription (Horseman \& Yu-Lee 1994, Hynes et al. 1997). The findings of this study would suggest that STAT5 does not directly alter EGF transcription. However, the results do not rule out the possibility of a STAT5-responsive gene being involved in regulating EGF transcription.

The present studies indicate that a YY1 binding site in the $5^{\prime}$ flank of the EGF gene is critical for hormonal regulation of the gene, at least in the context of the mammary gland. YY1 (Yin-Yang-1, also known as $\delta$ factor or NF-E1) is a multifunctional nuclear factor that acts as a transcription initiator or promotion factor for several genes, including immunoglobulin heavy chain, $c$-myc, rpL30, rpL32 and dihydrofoleate reductase (Shrivastava \& Calame 1994). However, YY1 has also been shown to inhibit transcription of other genes, including $c$-fos, immunoglobulin $\kappa$ chain, $\alpha$-actin, $\varepsilon$-globulin, serum amyloid and $\beta$-casein (Shrivastava \& Calame 1994). The finding that YY1 may play a part in regulating EGF expression in the mammary gland shows an obvious parallel with the $\beta$-casein gene, in which a YY1 site has also been proposed (Meier \& Groner 1994). Unlike others who found that in the $\beta$-casein gene there is a STAT5 binding site present adjacent to the
YY1 site that may remove YY1 inhibition by competition (Meier \& Groner 1994), we have not found a definitive binding site for another transcription factor in such close proximity to the YY1 site. However, this lack of identification of a positive regulator does not prove that it is absent.

In addition to prolactin, the expression of EGF, in common with that of $\beta$-casein, appeared to require the presence of glucocorticoids. The $\beta$-casein gene appears to respond to glucocorticoids through a well-recognized glucocorticoid response element (Doppler et al. 1989). No consensus glucocorticoid response element was identified on the EGF 5' flank, but possible cryptic half-sites (GGTCCC begining at -244 and TGTTCC, beginning at -225) were present flanking the YY1 sequence. Although we have not been able definitively to show glucocorticoid receptor binding to these sites, the possibility of their involvement in regulating YY1 interaction with the EGF 5' flank remains.

Although the mutagenesis studies indicated that the YY1 site on the EGF 5' flanking sequence (or a binding site overlapping the YY1 site) has a critical role in regulating EGF transcription, the exact identity of the protein interacting with the sequence is equivocal. Our results indicate that YY1 is capable of interacting with the site, but an additional protein, probably not YY1, also appears to interact with the sequence, or an overlapping sequence. Gelshift and western blot analysis indicates that YY1 content and DNA binding activity are unaffected by hormone treatment, as was observed in HC11 cells by Meier \& Groner (1994). Raught et al. (1994) observed increased YY1-DNA interaction during lactation in vivo. However, comparisons of these results should be made with caution. HC11 cells show heterogeneity in their accumulation of $\beta$-casein in response to lactogenic hormones, with only a relatively small percentage expressing immunologically detectable $\beta$-casein $24 \mathrm{~h}$ after hormone treatment (Ball et al. 1988). Thus, it is possible that YY1 changes in a relatively small subset of $\mathrm{HC11}$ cells that account for the hormone responsiveness, and that this change might not be detected by the methods used. In addition, the gelshift analysis from these experiments suggests the possibility that a factor other than YY1, which appears to be decreased in content or DNA binding activity in response to insulin, glucocorticoids and prolactin, can bind at or near the YY1 binding site.

The observation of a factor apparently distinct from YY1 that appears to interact at or near the YY1 site may indicate an important regulatory mechanism at this site. The fact that this protein, or 
its interaction with the YY1 site, is hormonally regulated is of considerable interest, and could indicate that hormonal removal of transcriptional repression at the YY1 site is via removal of this protein, rather than of authentic YY1. At present, the identity of this protein remains unknown. However, identification of the protein and its regulation may provide important insights into the regulation of EGF transcription.

The present results indicate that a combination of three distinct hormones, insulin, prolactin and dexamethasone, is required to increase transcription of the EGF gene. Such results have been shown previously for other milk protein genes, such as caseins (Topper \& Freeman 1980). However, this observation poses interesting mechanistic questions, particularly in light of the present findings that removal of YY1 repression appears to be a key feature in regulating EGF gene expression. How three distinct hormones might affect such a site remains uncertain. Importantly, the time-course studies suggest that regulation of EGF expression requires several hours, which suggests the possibility that regulation of EGF transcription may be downstream of other genes, although this has not been shown definitively. Thus the three distinct hormones may not actually be acting at a single site on the EGF gene, but could be affecting that site via distinct sites on other genes. In addition, the possibility that these hormones affect EGF transcription in ways undetected in these studies (for example, by influencing sites located outside the regions studied) must also be considered.

\section{ACKNOWLEDGEMENTS}

The authors would like to thank Dr J C Pascall (Cambridge Research Station, Cambridge, UK) for providing the clone of the EGF 5' flanking sequence and $\operatorname{Dr} B$ Groner (Institute for Experimental Cancer, Freiburg, Germany) for providing the HC11 cells used in these studies. Funding was provided by USDA projects WIS 3769 and 3557.

\section{REFERENCES}

Ball RK, Friis RR, Schoenenberger CA, Doppler W \& Groner B 1988 Prolactin regulation of beta-casein gene expression and of a cytosolic $120 \mathrm{Kd}$ protein in a cloned mouse mammary epithelial cell line. EMBO fournal 7 2089-2095.

Beardmore JM \& Richards RC 1983 Concentration of epidermal growth factor in mouse milk throughout lactation. Fournal of Endocrinology 96 287-293.

Brown GF, Teng CT, Pentecost BT \& DiAugustine RP 1989 Epidermal growth factor precursor in mouse lactating mammary gland alveolar cells. Molecular Endocrinology 3 1077-1083.
Carpenter G 1980 Epidermal growth factor is a major growth promoting agent in human milk. Science 210 198-203.

Chomczynski P \& Sacchi N 1987 Single-step method of RNA isolation by acid guanidinium thiocyanate-phenolchloroform extraction. Analytical Biochemistry 162 156-159.

Doppler W, Groner B \& Ball RK 1989 Prolactin and glucocorticoid hormones synergistically induce expression of transfected rat $\beta$-casein gene promoter constructs in a mammary epithelial cell line. Proceedings of the National Academy of Sciences of the USA 86 104-108.

Fenton SE \& Sheffield LG 1991 Lactogenic hormones increase epidermal growth factor message RNA content of mouse mammary glands. Biochemical and Biophysical Research Communications 181 1063-1069.

Fenton SE \& Sheffield LG 1994 Control of mammary epithelial cell DNA synthesis by epidermal growth factor, cholera toxin and IGF-1: specific inhibitory effect of prolactin on EGF-stimulated cell growth. Experimental Cell Research 210 102-106.

Fenton SE, Groce NS \& Lee DC 1996 Characterization of the mouse epidermal growth factor promoter and 5 '-flanking region. Fournal of Biological Chemistry 271 30870-30878.

Fisher DA \& Lakshmanan J 1990 Metabolism and effects of epidermal growth factor and related growth factors in mammals. Endocrine Reviews 11 418-443.

Gray A, Dull TJ \& Ulrich A 1983 Nucleotide sequence of epidermal growth factor cDNA predicts a 128000 molecular weight precursor. Nature 303 703-705.

Gubits RM, Shaw PA, Gresik EW, Onetti-Muda A \& Barka T 1986 Epidermal growth factor gene expression is regulated differently in mouse kidney and submandibular gland. Endocrinology 119 1382-1387.

Horseman ND \& Yu-Lee L 1994 Transcriptional regulation by the helix bundle peptide hormones: growth hormone, prolactin, and hematopoietic cytokine. Endocrine Reviews 15 $627-769$.

Hynes NE, Cella N \& Wartmann M 1997 Prolactin mediated intracellular signaling in mammary epithelial cells. Fournal of Mammary Gland Biology and Neoplasia 2 19-27.

Jahnke GD, Chao J, Walker MP \& DiAugustine RP 1994 Detection of a kallikrein in the mouse lactating mammary gland: a possible processing enzyme for the epidermal growth factor precursor. Endocrinology 135 2022-2029.

Kadowaki H, Kadowaki T, Wondisford FE \& Taylor SI 1989 Use of polymerase chain reaction catalyzed by Taq DNA polymerase for site-specific mutagenesis. Gene $\mathbf{7 6}$ 161-166.

Kasayama S, Yoshimura M \& Oka T 1989 The regulation by thyroid hormones and androgen of epidermal growth factor synthesis in the submandibular gland and its plasma concentrations in mice. Fournal of Endocrinology 121 269-275.

Meier VS \& Groner B 1994 The nuclear factor YY1 participates in repression of the $\beta$-casein gene promoter in mammary epithelial cells and is counteracted by mammary gland factor during lactogenic hormone induction. Molecular and Cellular Biology 14 128-137.

Mroczkowski B \& Reich M 1993 Identification of biologically active epidermal growth factor precursor in human fluids and secretions. Endocrinology 132 417-425.

Pascall JC \& Brown KD 1988 Structural analysis of the 5 -flanking sequence of the mouse epidermal growth factor gene. Fournal of Molecular Endocrinology 1 5-10.

Pascall JC, Saunders J, Blakely DM, Laurie MS \& Brown KD 1989 Tissue-specific effects of castration and ovariectomy on murine epidermal growth factor and its mRNA. Fournal of Endocrinology 121 501-506. 
Pascall JC, Surani MA, Barton SC, Vaughan TJ \& Brown KD 1994 Directed expression of simian virus $40 \mathrm{~T}$-antigen in transgenic mice using the epidermal growth factor gene promoter. Fournal of Molecular Endocrinology 12 313-325.

Price PM, Megyesi J, Saggi S \& Safirstein RL 1995 Regulation of transcription by the rat EGF gene promoter in normal and ischemic murine kidney cells. American Fournal of Physiology 268 F664-F670.

Raught B, Khursheed B, Kazansky A \& Rosen J 1994 YY1 represses $\beta$-casein gene expression by preventing the formation of a lactation-association complex. Molecular and Cellular Biology 14 1752-1763.

Scott J, Urdea M, Quiroga M, Sanchez-Pescador R, Fong N, Selby M, Ruth WJ \& Bell GI 1983 Structure of a mouse submaxillary messenger RNA encoding epidermal growth factor and seven related proteins. Science 221 236-240.

Shrivastava A \& Calame K 1994 An analysis of genes regulated by the multi-functional transcriptional regulator Yin Yang-1. Nucleic Acids Research 22 5151-5155.
Snedeker SM, Brown CF, \& DiAugustine RP 1991 Expression and functional properties of transforming growth factor- $\alpha$ and epidermal growth factor during mouse mammary gland ductal morphogenesis. Proceedings of the National Academy of Sciences of the USA 88 276-280.

Steel RGD \& Torrie JH 1980 Principles and Procedures of Statistics. New York: McGraw-Hill Book Company.

Thulesen J, Raaberg L, Nexo E, Madsen EL \& Poulsen SS 1993 Epidermal growth factor in mammary glands and milk from rats: the influence of insulin. Diabetes Research and Clinical Practice 21 11-18.

Topper YJ \& Freeman CS 1980 Multiple hormone interactions in the developmental biology of the mammary gland. Physiological Reviews 60 1049-1106.

Ye J, Young HA, Ortaldo JR \& Ghosh P 1994 Identification of a DNA binding site for the nuclear factor YY1 in the human GM-CSF core promoter. Nucleic Acids Research 22 5672-5678.

REVISED MANUSCRIPT RECEIVED 30 October 1997 